\title{
Impact of Milk Collection Centers on Dairy Production System in the Newly Reclaimed Area of Nubaria Sahar A. Abd-Elrahaeim ${ }^{1}$ and Dalia Yassin ${ }^{2}$ \\ ${ }^{1}$ Animal Production Research Institute \\ ${ }^{2}$ Agricultural Economics Research Center \\ Nadi Elsaid St., Dokki, Giza (Email: Sahar_2007@hotmail.com
}

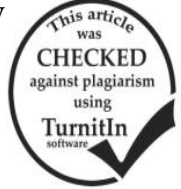

\section{ABSTRACT}

This study was implemented to investigate the effect of Milk Collection Centers, MCC, as a major intervention affecting milk production system. Four villages were selected in the Nubaria area; two of which have collection centers and the other did not. A hundred farmers from the 4 villages (25 each) was randomly selected and interviewed and information was collected in a semistructured questionnaire. Results indicated the significant impacts on different parameters of the system including production resources (number of paid labor and their salaries, more land holding areas, cropping pattern and herd structure). Farmers in villages with MCC tend to increase area cultivated with forages for providing animal feeds and prefer of keeping more buffalo, as their fatrich whit milk is customer-preferred. Framers in villages with MCC pay more attention to the feeding of their animals e.g. giving more concentrates and silage, as well as to producing cleaner milk utilizing machine milking and practice milking in separate places out of barns. These practices are paid off in terms of increasing milk productivity and price of milk, and therefore the total income from dairy production. Paralally farmers also targeted genetic improvement practices, i.e. utilization of AI, instead of natural mating. These findings indicate the need of spreading the MCC over all villages in the reclaimed area, as well as, old delta lands, in order to improve the dairy production system and increasing farm income. In spite of the fact that the studied villages have been assumed to be for newly graduates, the majority of interviewed farmers were not graduates; rather they were old farmers from the delta who purchased those lands from the graduates. This situation of graduates selling their lands, instead of settling needs more investigation to identify reasons behind and means of solving such a problem.

Keywords: dairy production system, newly reclaimed land, Milk Collection Centers

\section{INTRODUCTION}

The production of milk from both buffaloes and cows is increasing at a higher rate than the growth of the Egyptian population, leading to an increased per capita share of milk (Alary et al 2016). Egypt depends on its production of dairy products from buffalo and cattle, where buffalo is the important source of dairy production and surpasses local cows in productivity. The production of buffalo head is about 1,606 liter per year compared to about $700 \mathrm{~kg}$ of head from local cattle.

Milk and its products are considered to be a major food sources because they contain the basic components needed by the body to build protein, fats, sugars, minerals and vitamins. Milk is economically considered one of the cheapest types of animal protein. Milk is also important for sustaining a large sector of small rural and urban producers.

Egypt was the 37th cow milk producer in the world with 3.1 million tons and the $4^{\text {th }}$ buffalo milk producer with 2.6 million tons in 2011/12 after Asian countries (India, Pakistan and China) (FAOSTAT, 2011 $\&$ 2012). In the Mediterranean region, Egypt was the third producer of cheese after France and Italy with 310,000 tons in 2001 (RAC/CP, 2002). Nutritionally, it provides Egyptian population with animal protein 7.4 $\mathrm{g} /$ day (out of $20 \mathrm{~g}$ ), $10.5 \mathrm{~g}$ of fat /day (out of 18.3) \& $159 \mathrm{cal} /$ day energy (out of $277 \mathrm{cal}$ ). SADS 2030, give priority for milk (after fish and poultry) as efficient way of utilizing feed and water, under the prevailing water scarcity and feed shortage.

The dairy production system in the newly reclaimed lands, e.g. Nubaria I different from those in the old delta lands. It is characterized with low dense populated village, where the cultivated land is located out of the village. Plots are geometrical lots attributed by the administration belonging to an "irrigated entity".
The low density in the village allows keeping the animals in the village, so few animals are moving to the plots. The community in the newly reclaimed lands can be classified into three majors social categories: 1) the university graduates (UG) who have been the main targeted beneficiaries of these lands during the first settling plan, 2) the land tenants of the old lands who have benefited of these lands in the last 2 decades following to the land policies that are put an end of the inheritance on rent land, and 3) the new buyers who have bought these lands from the o $\square$ cial beneficiaries. The third group now is the prevailing one, on the expenses of the $1^{\text {st }}$ category (Osman et al, 2014). The dairy sector suffers from many production and marketing problems, especially among small producers, including low efficiency of the handling and marketing systems and the high percentage of loss and damage, which is a negative impact on the quantities of milk produced. Therefore, the study concerned the study of this system shedding light on it, with a focus on the study of technical variables through which this system and how it affects the efficiency of productivity to perform Ruminants produced.

The main objective of this study is to characterize dairy production system in the newly reclaimed area of Nubaria region and to analyze it weaknesses and strengths points, challenges and opportunities and how to strengthen its weaknesses to improve this sector in Nubaria area.

\section{MATERIALS AND METHODS}

The present study was conducted in four villages two of which has Milk Collection Centers, MCC (ElHuda and El-Rakhaa villages) and the other two do not have, NMCC (karia 2, and Karia 3 villages) of Nubaria region. A total of 100 producers having total number of 407 dairy animals (buffalos and cows) from the four villages were interviewed. Data collected through semi- 
structured interview, with questionnaire filled during interviewing the 100 dairy farmers. Before the actually implementation of the field survey, a 10\% (10 farmers) joined a pretesting semi-structured questionnaire was carried out by interviewing 10 dairy farmers in the Nubaria region. Based on the responses of interviewed dairy farmers, the prepared semi-structure questionnaire was modified and an interview was conducted to collect the required data. Data covered social, production resources, herd management, supply chain, marketing and income, and veterinary services and diseases parameters for characterization of the system.

The Nubaria region was selected for this study because it is considered the major reclaimed area (outside the valley) as the percentage of dairy cattle in Nubaria is $82 \%$ of the total dairy cattle outside the valley (and $18.6 \%$ of the percentage of total national dairy cattle herd in Egypt) (MALR 2015). The existence of the MCC is the major effect investigated in this study.

\section{Data analysis}

Data collection through semi-structured questionnaire was coded, entered and analyzed by using SAS 9.3 (SAS Institute, Cary NC), following the model:

\section{Where:}

$$
\mathbf{Y}_{\mathrm{ijk}}=\mathbf{u}+\mathbf{c c}_{\mathbf{i}}+\mathbf{e}_{\mathbf{i j}} \text {, }
$$

$\mathrm{Y}_{\mathrm{ijk}}$ is an individual observed traits $\mathrm{y}$,

$\mathrm{U}$ is the overall mean,

$\mathrm{CC}_{\mathrm{i}}$ is the effect due to Milk Collection Center, $\mathrm{i}=1$ or 2; 1= existence of Milk Collection Center (MCC), 2 =Non-existence of Milk Collection Centers (NMCC), and $\mathrm{e}_{\mathrm{ij}}$ is an error attached to the ij observation.

SWOT analysis was performed to study the Strength, Weaknesses (external factors), Opportunities and Threats (internal factors) of the milk production, processing and marketing in the system prevailed in the studied villages. SWOT was performed according to (Burkart et al, 2011).

\section{RESULTS AND DISCUSSION}

1. Social Parameters: Social parameters include family size and education.

a. Family size: Table (1) presented the average of the family size and minimum, maximum family size; this number did not include the grandparents in the studied areas.

Table 1. Average of family size (person/family) and age of householders in the studied villages.

\begin{tabular}{lcccccc}
\hline Items & \multicolumn{3}{c}{$\begin{array}{c}\text { Milk Collection } \\
\text { Centers } \\
\text { Mean }\end{array}$} & \multicolumn{3}{c}{$\begin{array}{c}\text { Mo Min. Collection } \\
\text { Centers }\end{array}$} \\
& 6 & 1 & 10 & 5 & 4 & 7 \\
\hline Family & $6 a x$. & Mean & Min. & Max. \\
Size & 33 & 2 & 67 & 32 & 2 & 72 \\
Age & &
\end{tabular}

The mean of family size per householder was 6,5 person/family in MCC and NMCC respectively, While the average of ages was 33 years in the MCC and 32 years in the NMCC. No significant difference in either family size or ages due to MCC has been detected.

\section{b. Literacy and education:}

Fig (1) illustrates percentage the education status for farmers in the studied areas according to the existence of MMC. Higher level of education was reported in the villages with MCC e.g. University degree (13\%) and High school $(35 \%)$ versus $3 \%$ with university degree and $29 \%$ with high school degrees in NMCC. An association between existence of MCC and higher education level has been proved. This situation might be due to increasing farm income, which enables continuing education to upper levels.

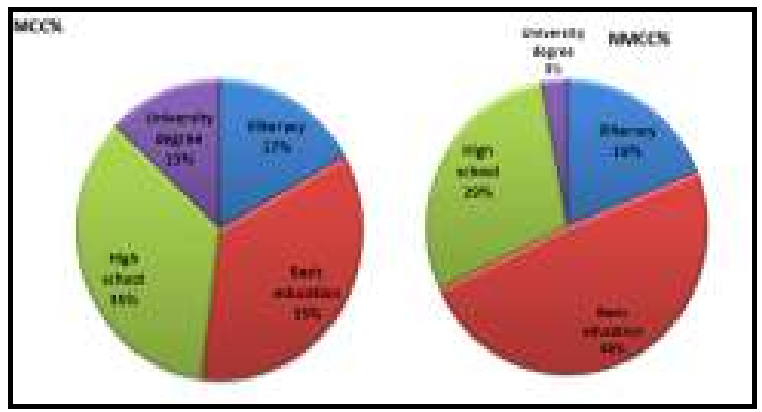

Figure 1. Education levels (\%) of the producers in the studied villages.

\section{Production Resources:}

The production resources include cultivated area (land), labor and livestock.

\section{a. Labor:}

The data collected showed that all the milk producers included in this study had based their milk production on the use of family labor which represented $82 \%$ and $100 \%$ with MCC and NMCC, while 16\% depend on rented paid labor in MCC (Table 2). This indicates that existence of MCC promote the need for more labor that cannot be provided only by family. This within-farm shortage in labor forces resulted in hiring more labor and creation of more job opportunities in the community. The monthly salary ranges between LE 900 and LE 1200. Experience years in dairy production business for milk producers were about 12 years in the two groups of villages (Table 3 ).

Table 2. The labor type in the studied villages.

\begin{tabular}{|c|c|c|c|c|}
\hline \multirow{2}{*}{ Labor type } & \multicolumn{2}{|c|}{$\begin{array}{c}\text { Milk Collection } \\
\text { Center }\end{array}$} & \multicolumn{2}{|c|}{$\begin{array}{c}\text { No Milk } \\
\text { Collection Center }\end{array}$} \\
\hline & $\mathbf{N}$ & $\%$ & $\mathbf{N}$ & $\%$ \\
\hline Family & 41 & 82 & 50 & 100 \\
\hline Rented & 8 & 16 & 0 & 0 \\
\hline Family \& rented & 1 & 2 & 0 & 0 \\
\hline
\end{tabular}

\section{b. Land holding:}

Table (4) presents the percentage of different types of land holding in the studied areas. Owner of land presents $88 \%$ and $90 \%$ in MCC and NMCC, respectively. Only $8 \%$ and $10 \%$ of interviewed farmers were renting land in MCC and NMCC, respectively. Table (5) indicated that the average area of owned land holdings in the sampled producers in selected areas was $5.95(\sim 6)$ feddan and 3.10 feddan in MCC and NMCC, respectively. Table (5) showed significantly larger owned land plots in the MCC villages indicating the effect of MCC in encouraging holding more producing animals and utilizing more area 
for forage production, which is available only if the farmer has more land to cultivate. Average area rented in the MCC were also significantly higher in the MCC 0.78 fed. vs. 0.35 fed in the NMCC villages. The average rent value was much higher in the MCC villages lands (LE 5,000) in comparison to only LE 3,833 in NMCC villages.

Table 3. number and labor, labor cost (LE) in the studied villages

\begin{tabular}{lcccccc}
\hline \multirow{2}{*}{ Item } & \multicolumn{3}{c}{ Milk Collection Center } & \multicolumn{3}{c}{ No Milk Collection Center } \\
& Mean & Min. & Max. & Mean & Min. & Max. \\
\hline No .Hired labor & 2 & 2 & 3 & 0 & 0 & 0 \\
Work hours & 12 & 12 & 12 & 0 & 0 & 0 \\
Labor cost/LE/month & 933 & 900 & 1200 & 0 & 0 & 0 \\
Experience years for milk producers & 12 & 3 & 27 & 12 & 4 & 17 \\
\hline
\end{tabular}

Table 4. The percentage of land holding in the studied villages

\begin{tabular}{lcc}
\hline Item & $\begin{array}{c}\text { Milk Collection } \\
\text { Center \% }\end{array}$ & $\begin{array}{c}\text { No Milk Collection } \\
\text { Center \% }\end{array}$ \\
\hline Owner & 88 & 90 \\
Rented land & 8 & 10 \\
Owner\& & 4 & 0 \\
Rented land & 4 & 0 \\
\hline
\end{tabular}

Table 5. The Mean $\pm \mathrm{SE}$ of land holding, area rented in the studied villages

\begin{tabular}{lcc}
\hline Item & $\begin{array}{c}\text { Milk } \\
\text { Collection } \\
\text { Center }\end{array}$ & $\begin{array}{c}\text { No } \\
\text { Milk Collection } \\
\text { Center }\end{array}$ \\
\hline Area owned (Fed) & $5.95 \pm 0.563^{\mathrm{a}}$ & $3.10 \pm 0.563^{\mathrm{b}}$ \\
Area rented(Fed) & $0.782 \pm 0.268^{\mathrm{a}}$ & $0.35 \pm 0.268^{\mathrm{b}}$ \\
\hline $\begin{array}{l}\text { Means with different letters within the same raw are significantly } \\
\text { different }(\mathbf{p}<\mathbf{0 . 0 0 1})\end{array}$ &
\end{tabular}

c. Crops pattern:

In summer the land cultivated with Darawa (green corn plant) and Corn in MCC, while the land was cultivated with corn, vegetables, oil crops, cotton in the NMCC villages. In winter, land is cultivated with wheat and berseem (green fodder) in MCC; and vegetables, oil crops and bean in the NMCC (Table 6). As shown in Table (6), green fodder is a major component in both winter (berseem) and summer (Darawa) in MCC. In the MCC, $51 \%$ of farmers in summer and $49 \%$ in winter cultivate forages, while in the NMCC, the highest percentage of farmers cultivate corn in the summer (41\%) and vegetables $(79 \%)$ in winter. This indicated the tendency of farmers to cultivate more forages (Darawa in summer and Berseem in winter) in the MCC villages for better feeding of dairy animals to produce more milk to be marketed in the available MCC.

Table 6. Percentage of crops pattern in The MCC and NMCC.

\begin{tabular}{lcccc}
\hline \multirow{2}{*}{ Crops } & \multicolumn{2}{c}{ Milk Collection Center \% } & \multicolumn{2}{c}{ No Milk Collection Center \% } \\
\cline { 2 - 5 } & Summer & Winter & Summer & Winter \\
\hline Wheat & 0 & 51 & 0 & 0 \\
Green fodder* & 51 & 49 & 0 & 0 \\
Corn & 49 & 0 & 41 & 0 \\
Vegetables & 0 & 0 & 38 & 5 \\
Oil crops & 0 & 0 & 0 & 18 \\
Bean & 0 & 0 & 3 & 0 \\
Cotton & 0 & 0 & 0 & 16 \\
\hline
\end{tabular}

* Green fodder $=$ Berseem in winter and Darawa in summer

\section{d. Herd Structure:}

Percentage of dairy buffalo's holders in NMCC villages $(4.37 \%)$ was much lower than those in MCC $(20.1 \%)$, revealing the preference of farmers to keep buffalo in the MCC villages in comparison to the NMCC ones for producing more buffalo milk. Buffalo milk is known to have higher price in the MCC (and all types of customer) in Egypt due to customer preference for fatrich and white colored buffalo milk. Average herd size in dairy animals in MCC was 4.3 cow and 3.8 buffaloes while it was 2.3 cows and 1.5 buffaloes in NMCC. Cows present more dairy animals in NMCC villages $(26.8 \%)$ in comparison to the MCC ones (22.97\%), as indicated in Table (7).

The percentage of livestock is presented in table (8). It was found that the villages with milk collection centers depend on a mixed dairy herd of cows and buffalo animals $(80 \%)$, whereas the villages without MCC tend to keep the crossbred cows only (80\%). Producers showed limited reliance on only buffalo milk, that does not exceed $2 \%$ in both the MCC and NMCC villages. This may be due to the higher milk productivity of Crossbred cows than buffalos.

e. In/Outlet of dairy livestock: In the villages where MCC are found, the percentage of livestock (cows and buffaloes) purchased from the surrounding markets and neighbors were $67 \%$ and $33 \%$, respectively. While the sale of livestock through the surrounding markets was $54 \%$ and for neighbors was $46 \%$. The farmers in the villages that do not have collection centers purchased their livestock from the surrounding markets by $54 \%$ and through neighbors by $46 \%$ while the sale of livestock through neighbors was $81 \%$ or through the surrounding markets by $19 \%$.

\section{f. Buying and selling livestock:}

Main reasons for animals purchase in the villages with MCC are to increase the size of the buffalo dairy herd (98\%) and culling/replacement of dairy animals $(2 \%)$. Conversely, in the NMCC villages, more farmers purchased animals for culling/replacement (78\%) and less for increasing the herd size $(20 \%)$. In villages with milk collection centers, livestock are sold because of ageing or to obtain cash $(69 \%)$, low production or the presence of 
reproductive problems $(31 \%)$. On the other hand animals are sold in NMCC villages in order to obtain cash or aging $(57 \%)$ versus $43 \%$ due to low production or reproductive problems. Concerning the dairy animal price, in MCC villages.

\section{Herd Management}

\section{a. Housing system:}

Herds were kept tied in barns made of limestone and covered with concrete. Floor was covered by concrete. Barns were always supplied with water provided with tap water and electricity. In NMCC villages almost $100 \%$ of livestock are kept tied in closed barns within the same building where the holders live. In MCC villages, about $92 \%$ of animals are kept in separate barns attached to the house (Table 9).

Table 7. Herd structure in the studied villages

\begin{tabular}{lcccc}
\hline Species & $\begin{array}{c}\text { Milk } \\
\text { Collection } \\
\text { Center }\end{array}$ & \multicolumn{2}{c}{$\begin{array}{c}\text { No } \\
\text { Milk Collection } \\
\text { Center }\end{array}$} \\
& N & \% & N & \% \\
\hline Cow only & 9 & 18 & 40 & 80 \\
Buffaloes only & 1 & 2 & 1 & 2 \\
Cow and buffaloes & 40 & 80 & 9 & 18 \\
\hline
\end{tabular}

Table 8. The distribution of livestock in the studied

\begin{tabular}{lcccc}
\multicolumn{1}{c}{ villages } & \multicolumn{2}{c}{$\begin{array}{c}\text { Milk } \\
\text { Collection } \\
\text { Center }\end{array}$} & \multicolumn{2}{c}{$\begin{array}{c}\text { No Milk } \\
\text { Collection } \\
\text { Center }\end{array}$} \\
& N & \% & N & \% \\
\hline Cow & 48 & 22.97 & 49 & 26.78 \\
Buffaloes & 42 & 20.10 & 8 & 4.37 \\
Goat & 35 & 16.75 & 43 & 23.50 \\
Sheep & 34 & 16.27 & 41 & 22.40 \\
Camel & 1 & 0.48 & 0 & 0 \\
Donkeys and horses & 49 & 23.44 & 42 & 22.95 \\
\hline
\end{tabular}

Table 9. Housing system in the study villages $(\%)$

\begin{tabular}{lcc}
\hline Items & $\begin{array}{c}\text { Milk } \\
\text { Collection } \\
\text { Center\% }\end{array}$ & $\begin{array}{c}\text { No Milk } \\
\text { Collection } \\
\text { Center\% }\end{array}$ \\
\hline $\begin{array}{l}\text { Closed barns inside house } \\
\text { Separate barns attached } \\
\text { to the house }\end{array}$ & 8 & 100 \\
\hline
\end{tabular}

\section{b. Animal Manure:}

In MCC villages, $48 \%$ of the manure was sold to other farmers and $52 \%$ was used by the farms themselves, when they have cultivated lands. While in the NMCC a $100 \%$ of the manure is sold to others. About $70 \%$ and $78 \%$ of farmers collect animal manure in their land until use in MCC and NMCC, respectively; while about $30 \%$ of farmers collect the manure in a special place next to the house in the MCC and $22 \%$ in the NMCC. The majority of dairy producers buried their dead animals in both MCC and NMCC through villages. c. Feeding system:

In the MCC villages, the largest proportion of Feedstuffs used in animal feed in summer was Concentrates $(31 \%)$ followed by Berseem Hay and silage; about $(30 \%)$ and $(23 \%)$, respectively. In the NMCC villages, the largest percentage of feedstuffs used was wheat Straw, followed by Concentrates, and Berseem hay (about 35\%, 31\% and 34\%, respectively). In the MCC villages, the percentage of animal feeds used in winter was $40 \%$ concentrates, followed by
$36.7 \%$ of green fodder, while in the NMCC utilized green fodder was the highest used feed stuff (87.5). In the MCC villages, farmers provide larger quantities of concentrate in both winter and summer, for supporting livestock to produce larger amounts of milk. While in the NMCC, farmers tend to provide much more green fodder in winter, to minimize feed cost on the expenses of milk productivity, and they do not cultivate or provide green fodder in summer, as they pay more attention to the cash crops than they do for forages. This indicates the importance of green fodder in feeding milking animals. Table (10) shows the types of feedstuffs used in animal feeding in the studied area. Silage is only used in MCC villages $(23 \%$ in summer and $6.7 \%$ in winter) which indicates the adoption of this feeding intervention for keeping high milk productivity in summer and compensate less availability of forages, to be marketed in the MCC (Tables 10\&11). Results on animal feeding reflects that farmers in the studied villages provide more concentrated than the standards (Dry matter should b3 3\% of the life body weight with 40: 60 concentrates to roughages or 30: 70 concentrates to roughages)thus profitability from milk production is negatively affected by extra feeding cost. Milk producers needs training and extension on proper feeding.

Table 10. Percentage of feedstuffs used in animal feeding in the studied villages

\begin{tabular}{lcccc}
\hline Feedstuffs & \multicolumn{2}{c}{$\begin{array}{c}\text { Milk Collection } \\
\text { Center }\end{array}$} & \multicolumn{2}{c}{$\begin{array}{c}\text { No Milk } \\
\text { Collection Center }\end{array}$} \\
& Summer & Winter & Summer & Winter \\
\hline Green fodder* & 4 & 36.7 & - & 87.5 \\
Straw & 12 & 10.8 & 35 & 1.8 \\
(roughages) & 30 & 5.8 & 31 & 1.8 \\
Hay & 31 & 40 & 34 & 3.6 \\
Concentrates & - & - & - & 5.4 \\
Wheat bran & 23 & 6.7 & - & - \\
Silage &
\end{tabular}

c. Fertility and reproductive management:

In the current study, artificial Insemination (AI) is applied by about $75 \%$ of farmers in the villages with MCC while farmers in the NMCC villages depend on the natural mating $(100 \%)$. That may be due to the producers in NMCC believe that the bull is more effective in getting the animals pregnant and that $\mathrm{AI}$ requires the presence of specialist. This result is in agreement with Abd El-Rahim (2005). There is inadequate information about the importance of AI technique in different developing countries (Fahim,2009; Dana, 1992; Dana and Kanbid , 1998). Relying on AI by $75 \%$ of farmers in villages with MCC reflect their targeted genetic improvement for milk productivity and increasing their farms' income. Farmers in each of the MCC and NMCC villages do not keep sires for breeding. The pregnancy diagnosis was determined by rectal palpation done by a veterinary doctor in about $89 \%$ and $100 \%$ in MCC and NMCC villages, respectively. It is noted that the farmers in both the MCC and the NMCC had experience in the diagnosis of estrous by observing some signs on the animals (e.g. high voice, jumping on other animals, raising tail, vaginal discharges, and anxiety/restless). Producers in MCC had not accounted by any calving difficulties in their animals; on the contrary, producers in NMCC suffer from problems in 
the parturition of their animals, such as uterine coup, which may be due to the farmers in NMCC villages pay more attention to naturally inseminate their cows with heavy weighted bulls, regardless the milk productivity traits. It was also noted that the farmers in both MCC and NMCC villages keep their born calves ( $98 \%$ for both) in the farm to increase the herd size and exercise culling/replacement of dairy animals from the withinfarm available animals as indicated in Table (12).

Table 11. Average quantities of feedstuffs consumed/

\begin{tabular}{|c|c|c|c|c|}
\hline \multicolumn{5}{|c|}{ head/ day (kg) } \\
\hline \multirow{2}{*}{ Feedstuffs } & \multicolumn{2}{|c|}{$\begin{array}{c}\text { Milk Collection } \\
\text { Center }\end{array}$} & \multicolumn{2}{|c|}{$\begin{array}{c}\text { No Milk Collection } \\
\text { Center }\end{array}$} \\
\hline & Summer & Winter & Summer & Winter \\
\hline $\begin{array}{l}\text { Green } \\
\text { fodder* }\end{array}$ & 15 & 21 & - & 40 \\
\hline Straw & 4.6 & 4 & 7 & 7 \\
\hline Hay & 7.2 & 5 & 3.4 & 3 \\
\hline Concentrates & 7.8 & 8.6 & 7 & 3 \\
\hline Wheat Bran & - & - & - & 3.5 \\
\hline Silage & 8 & 8.6 & - & - \\
\hline
\end{tabular}

Table 12. Percentages of calves raised in the studied areas

\begin{tabular}{lcc}
\hline Items & $\begin{array}{c}\text { Milk } \\
\text { Collection } \\
\text { Center\% }\end{array}$ & $\begin{array}{c}\text { No Milk } \\
\text { Collection } \\
\text { Center\% }\end{array}$ \\
\hline Calves raising & 98 & 98 \\
Yes & 2 & 2 \\
No & areas & \\
Why - Reason for calves raising & 76 \\
Increase number and & 65 & 12 \\
replacement & 33 & 12 \\
Improved strain & 2 & \\
Increase income & &
\end{tabular}

4. Marketing and Income

a. Sources of income: Surprisingly, analysis revealed that working in milk production (only) was the main job for the majority of farmers in the NMCC $(96 \%)$ versus $26 \%$ in the MCC villages, while having an additional job with milk production in MCC was $74 \%$. This percentage did not exceed $4 \%$ in the NMCC, Tables (13\&14). Concerning the value of income from different sources, analysis revealed that farmers of the MCC have significantly higher level of income from both dairy animals (LE 2,434 vs. 759.9 for the NMCC farmers), and from other jobs (LE4,070 vs. 1,130 for the NMCC farmers), and therefore the total income (Table 14), indicating their higher level of livelihood than the farmers in the NMCC.

b. Milking and milk marketing:

Milking is carried out twice a day (every 12 hours) using traditionally aluminum cans to collect the milk in both MCC and NMCC villages. Hand milking is applied in $100 \%$ studied farms in the NMCC, while $11 \%$ applied machine milking in the MCC villages. Farmers admit washed their hands before milking and cleaning the udder about $100 \%$ in MCC while only $80 \%$ in NMCC do that. In the NMCC villages, all animals are milked in the same place (Barn) they live in, while $72 \%$ of the animal is milked in a separate place in the MCC villages to keep cleaner milk production
(Table 16). Average storage period of milk until sold is 2 hours, during which, $52 \%$ of farmers in the MCC villages cool the milk before delivery vs. $64 \%$ in the NMCC villages (Table 18). No preservatives were added to milk in either MCC and NMCC farmers. When there was extra milk, farmers utilize it for home consumption $100 \%$ in NMCC vs. $89 \%$ in the MCC and $11 \%$ sell the rest of milk to neighbors (Table 18).

Table 13. Source of income for milk producers in the studied villages

\begin{tabular}{lcccc}
\hline Sources of income & $\begin{array}{c}\text { Milk } \\
\text { Collection } \\
\text { Center\% }\end{array}$ & \multicolumn{2}{c}{$\begin{array}{c}\text { No Milk } \\
\text { Collection } \\
\text { Center\% }\end{array}$} \\
& N & \% & N & \% \\
\hline $\begin{array}{l}\text { Work in milk production } \\
\text { only }\end{array}$ & 13 & 26 & 48 & 96 \\
$\begin{array}{l}\text { Having another job and } \\
\text { milk producers }\end{array}$ & 37 & 74 & 2 & 4 \\
\hline
\end{tabular}

Table 14. Means of Income sources of farmers in the studied areas

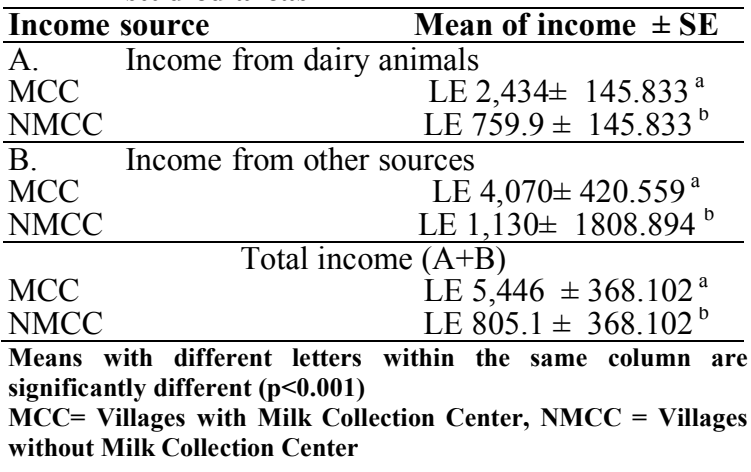

Table 15. Milk storage and utilization in the studied villages

\begin{tabular}{lcc}
\hline Item & $\begin{array}{c}\text { Milk } \\
\text { Collection } \\
\text { Center\% }\end{array}$ & $\begin{array}{c}\text { No Milk } \\
\text { Collection } \\
\text { Center\% }\end{array}$ \\
\hline Milk cooling & 52 & 64 \\
No Milk cooling & 48 & 36 \\
No Milk mixing & 58 & 98 \\
$\begin{array}{l}\text { Milk mixing (milk cow and } \\
\text { buffaloes) }\end{array}$ & 42 & 2 \\
$\begin{array}{l}\text { Home consumption of Extra } \\
\text { milk (Dairy processing) }\end{array}$ & 89 & 100 \\
Sell Extra milk to neighbors & 11 & 0 \\
\hline
\end{tabular}

Table 16. Marketing of produced milk in the studied villages

\begin{tabular}{|c|c|c|c|c|}
\hline \multirow[t]{2}{*}{ Supply chain } & \multicolumn{2}{|c|}{$\begin{array}{l}\text { Milk Collection } \\
\text { Center }\end{array}$} & \multicolumn{2}{|c|}{$\begin{array}{c}\text { No Milk } \\
\text { Collection Center }\end{array}$} \\
\hline & $\mathbf{N}$ & $\%$ & $\mathbf{N}$ & $\%$ \\
\hline $\begin{array}{l}\text { Milk collection } \\
\text { center }\end{array}$ & 40 & 80 & 0 & 0 \\
\hline Middlemen & 0 & 0 & 50 & 100 \\
\hline Wholesaler & 10 & 20 & 0 & 0 \\
\hline
\end{tabular}

\section{Supply chain:}

For the milk seller, $80 \%$ of farmers sell their milk to collection centers, while the other $20 \%$ do for wholesalers in the villages with MCC. In the NMCC villages, $100 \%$ of farmers sell their produced milk to middlemen (Table 16). This emphasizes that farmers in village with MCC guarantee sustainable marketing and higher price of milk 
than those in the villages without MCC. Table (17) shows that mean daily marketed milk and price (and therefore income) are much higher for the farmers in the MCC villages than those in the NMCC villages.

Table 17. mean amounts of daily marketed milk, its price and income in MCC and NMCC villages

\begin{tabular}{|c|c|c|c|c|}
\hline \multirow[b]{2}{*}{ Item } & \multicolumn{2}{|c|}{$\begin{array}{l}\text { Milk Collection } \\
\text { Center }\end{array}$} & \multicolumn{2}{|c|}{$\begin{array}{c}\text { No Milk Collection } \\
\text { Center }\end{array}$} \\
\hline & $\mathbf{N}$ & Mean \pm SE & $\mathbf{N}$ & Mean \pm SE \\
\hline $\begin{array}{l}\text { Total amount of } \\
\text { milk /day/farm }\end{array}$ & 50 & $27.6 \pm 1.772^{\mathrm{a}}$ & 50 & $10.2 \pm$ \\
\hline Price (LE) & 50 & $3.24 \pm 0.361^{\mathrm{a}}$ & 50 & $0.036^{\mathrm{b}}$ \\
\hline Income (LE) & 50 & $92.8 \pm 5.5998^{\mathrm{a}}$ & 50 & $27.96 \pm 5.3998^{b}$ \\
\hline
\end{tabular}

b. Common Diseases:The reported common diseases are those commonly found in Egypt; Foot and mouth disease (FMD) and internal parasites in addition to those associated with milk production and reproduction (calving difficulty, uterus inversion and Mastitis).

\section{Veterinary service and diseases}

a. Herd health care:

Farmers in the MCC pay much more health care to their animals than those of the NMCC. This is reflected as $86 \%$ farmers receive periodic vet. visit, while only $10 \%$ does in the NMCC (Table 18). Generally $100 \%$ farmers in both MCC and NMCC villages give regular vaccination to their animals; where $100 \%$ of NMCC farmers only rely on governmental veterinarians (which is usually free of charge), while $6 \%$ of the farmers in the MCC villages ask the visit of private veterinarians (Table 18). This reflects that MCC farmers have the well to pay for private veterinary service, in order to keep their animals healthy and producing more milk.

Table 18. Frequency of Veterinarian visit, cost and veterinarian service source in both MCC and NMCC farms in the studied villages

\begin{tabular}{|c|c|c|}
\hline Item & $\begin{array}{c}\text { Milk } \\
\text { Collection } \\
\text { Center\% } \\
\end{array}$ & $\begin{array}{c}\text { No Milk } \\
\text { Collection } \\
\text { Center\% }\end{array}$ \\
\hline $\begin{array}{l}\text { Periodic veterinary visits/ } \\
\text { check-out }\end{array}$ & 86 & 10 \\
\hline As needed visits of Vets. & 14 & 90 \\
\hline $\begin{array}{l}\text { Cost of visit the veterinarian } \\
\text { (Mean) }\end{array}$ & 64 & 0 \\
\hline Vaccination cost (Mean) & 53 & 0 \\
\hline $\begin{array}{l}\text { Vaccination } \\
\text { (governmental) }\end{array}$ & 94 & 100 \\
\hline $\begin{array}{l}\text { Vaccination } \\
\text { (private) }\end{array}$ & 6 & 0 \\
\hline
\end{tabular}

Table 19. SWOT analysis of the milk production, processing and marketing chain in the studied villages Strengths (S) Availability of a cheap workforce (family/paid)

Availability of cow's and buffalo's milk

Traditional know-how in dairy production

Basic activity of livestock keeping in the Egyptian culture Weaknesses (W)

Absence of quality control for milk

Low milk productivity from local dairy animals, and Lack of improved breeds of livestock

Shortage of skilled/trained staff

Absence of standardized specifications for

traditional dairy products

Lack of cooling \& storage transportation facilities

High incidence of animal diseases

Limited market access for small holders, and Absence of dairy cooperatives (groups)

Low milk yield of local livestock breeds

Lack of milk collection \& Distribution centers

Absence of public support services

Limited quantity, quality and high price of animal feed

Lack of automation \& cooling in the milking/transportation process

Poor farm sanitary and hygiene

High prices of packaging

Opportunities (O)

High public demand for milk

Milk processing \& consumption tradition of the society

Availability of dairy livestock

Awareness among dairy farmers and processors of the - benefits of cooperation

马ु Opportunities for local production of animal feeds.

. Unsatisfied national demand for milk and its products

Lack of milk collection/distribution centers

Opportunity for the private sector to invest in the dairy Æi supply chain

of Promising marketing prospects of traditional Egyptian dairy

products (e.g. Ras/Romi cheese) in the Arab and African markets

\section{SWOT analysis}

SWOT analysis stands for Strength-WeaknessesOpportunities-Threats, the first two elements are considered internal present measures, while the last two are external future-associated ones. The SWOT analysis represents the strengths, weaknesses, opportunities and threats of the dairy production/processing and marketing chains in the study area, and all Egypt.
Threats (T)

Reproductive problems

Absence of policies/regulations supporting dairy production, processing and marketing

Climate change

Uncertainty/absence of faire price for milk

Unstable political situation

High costs of dairy equipment (especially for cooling

transportation) and absence of subsidies

Rapid changes in the dairy technology

Lack of guaranteed reliable plan for importing animal feed

(e.g. soya bean and maize)

Complexity of import/export procedures.
SWOT (Table 23) resulted from the quantitative and qualitative analysis of the outcomes of interviews with farmers. Although SWOT results shown are not numerous (quantified), it should be taken into consideration that there are a good number of strengths/opportunities to take advantage of, and weaknesses/threats to be overcome. The formation of the dairy cluster could help in this process. Most interviewed farmers declared their knowledge of 
strengths, weaknesses, opportunities and threats in the dairy sector which can facilitate the strengthening of professional qualifications, solving feeding and marketing issues, improving hygiene standards, establishing distribution centers, etc.

\section{CONCLUSION}

1. Results indicated the significant effects of Milk Collection Center (MCC) on major parameters of dairy production system. MCC showed significant impacts on different production resources.

2. Theses present findings indicate the need of spreading the MCC over all villages in the reclaimed area, as well as, old delta lands, in order to improve the dairy production system and increasing farm income.

3. The phenomenon of graduates selling their lands, instead of settling needs more investigation to identify their problems means of solving them to encourage more graduated contributing to reclaiming activities.

\section{REFERENCES}

Alary V., C. Corniaux , A. Aboulnaga and S. Galal (eds.), 2016 .The traditional milk sector around Greater Cairo in Egypt.Montpellier CIRAD, APRI, ICARDA, Cairo University \& Ain Shams University, $61 \mathrm{p}$.

Abd El- Rahim, S.A. (2005) . A study on some milk production systems of Egyptian buffalo in Egypt . phD. Thesis . Fac. Agric., Cairo Univ., Egypt, 122p.

Stefan Burkarta, Federico Holmannb, Michael Petersb and Volker Hoffmanna (2011) SWOT analysis of smallholder livestock production in Colombia and Nicaragua from a meat consumers' perspective. Proceedings of the Conference on International Research on Food Security, Natural Resource Management and Rural Development, University of Bonn, October 5 - 7, 2011.
Dana , S.S. (1992) . Livestock owners and their knowledge about artificial insemination in livestock. Maha. J. of Exten. Edn., 11: 41-43.

Dana , S.S. and Kanbid , B.R. (1998). Impact of knowledge on attitude of livestock owners towards artificial insemination in cattle . Indian Vet. J., 75: 572-573.

Fahim,N.H. 2009. Performance of lactating buffaloes under the flying herds system in Egypt. Ph.D. Thesis. Faculty of Agric., Cairo University.

Food and Agriculture Organization of the United Nations (2011). FAOSTAT Statistics Database. :FAO, 2011. Print.

Food and Agriculture Organization of the United Nations (2012). FAOSTAT Statistics Database. :FAO, 2012. Print.

MALR (Ministry of Agriculture and Land Reclamation) . (2015). Annual Statistics, Animal Production Sector.

M. Osman, I. Daoud, S. Melak, E. Salah, Y. Hafez, A. Haggah, A. Aboul Naga, V. Alary, and J.F. Tourrand (2014) Revue d'élevage et de médecine vétérinaire des pays tropicaux, 2014, 67 (4): 201212

RAC/CP. 2002. Prevention of population in the dairy industry http: // fr.slideshare.net /paraskevi1975/ dairy-industry-egypt?related $=1$

SAS (2010). SAS 9.3 (SAS Institute, Cary, NC).

\section{اثر مر اكز تجميع الالبان علي منظومة إنتاج الالبان في مناطق حديثة الإستصلاح بالنوبارية

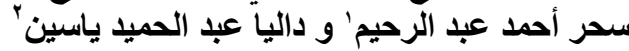

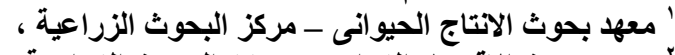

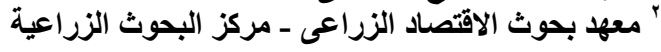

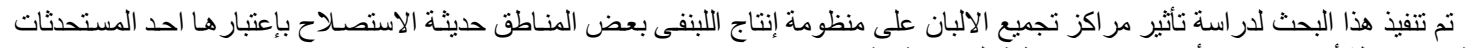

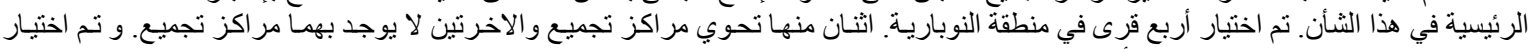

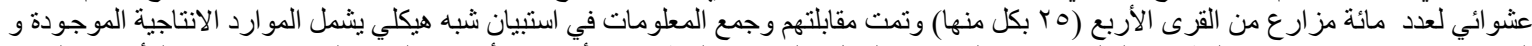

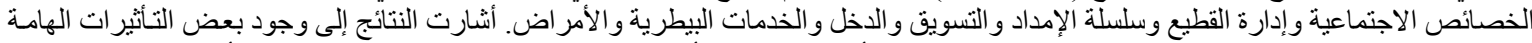

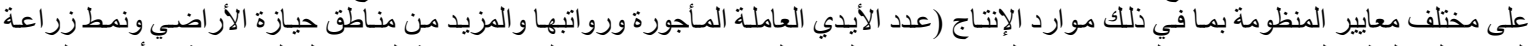

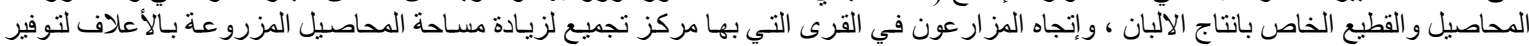

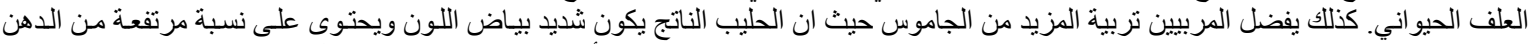

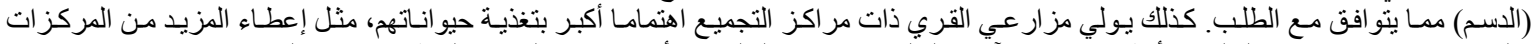

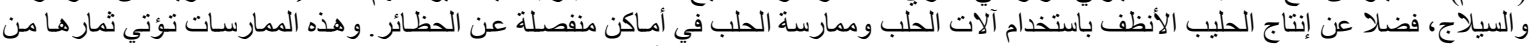

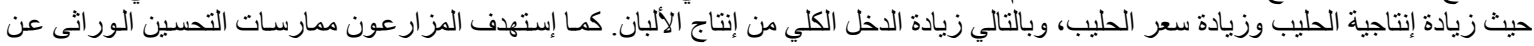

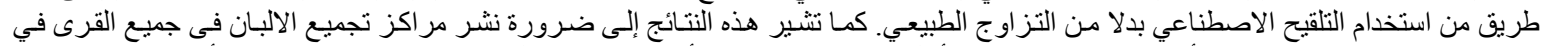

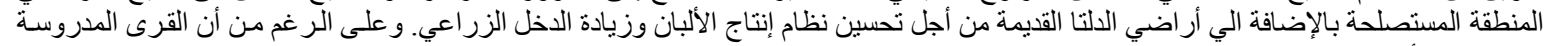

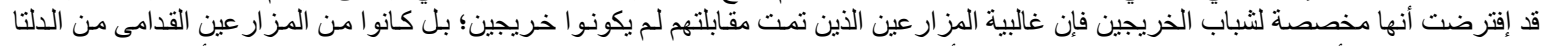

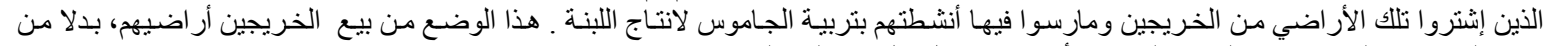

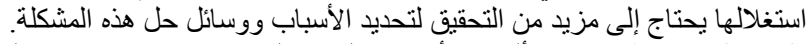

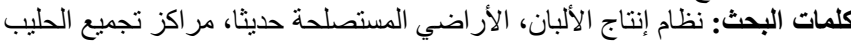

